\title{
FAKTOR-FAKTOR YANG MEMPENGARUHI TINGKAT PROFITABILITAS PERBANKAN SYARIAH DI INDONESIA (Studi Kasus pada Bank Umum Syariah di Indonesia Tahun 2009 -2012)
}

\begin{abstract}
Research on financial ratios and its effect to the profitability of banks in Indonesia have been carried out by several researchers, but research results are inconsistent. Profitability has essential means for long-term survival of banking business, because the profitability of the business showed good prospects in the future. This study intends to examine the effect of CAR, FDR, NPF, ROA, and ROA REO against Islamic bank in Indonesia. This explanatory research was conducted at the Islamic Commercial Bank at Bank Indonesia. Data collection was carried out in the documentation, in the form of financial ratios data from the financial statements of Islamic Banks gained per month of Islamic Commercial Bank Statistical Report published by Bank Indonesia in 2009-2012. The samples are 48 financial ratios of data taken by purposive sampling. Descriptive statistics are used to see an overview of research data individually, and multiple linear regression was used to test the hypothesis, where the previous requirement that the classical assumptions include normality, multicollinearity, heteroscedasticity, and autocorrelation have been fulfilled. The results of multiple linear regression showed the CAR regression coefficient on ROA is 0.026 with $p=0.024 ;$ FDR regression coefficient on $R O A$ is 0.009 with $p=0.007 ;$ NPF on ROA regression coefficient is 0.042 with $p=0.368$, regression coefficient on ROA REO by -1.53 with $p=0.000$, and the regression coefficient on ROA ROA of -0.029 with $p=0.000$. The test results demonstrate $F$ value 17.893 with $p=0.000$, and the test results adjusted $R^{2}$ 0.642 shows the explanatory power of the five independent variables in this study was $64.2 \%$ on ROA; remaining $35.8 \%$ is influenced by other factors are not included in the regression model. Concluded that partially CAR and FDR, respectively have a positive and significant effect to $R O A$, whereas $B O P O$ and $R E O$ have a negative and significant effect to ROA, but NPF have no significant effect on ROA.
\end{abstract}

Keywords: Profitability (ROA), CAR (Capital Adequacy Ratio), FDR (Financing to Deposit Ratio), NPF (Non Performing Financing), BOPO, and EOR (Operational Efficiency Ratio)

\section{PENDAHULUAN}

Bank merupakan suatu lembaga yang berperan sebagai perantara keuangan antara pihak-pihak yang memiliki dana dengan pihak-pihak yang memerlukan dana serta sebagai lembaga yang berfungsi nmemperlancar aliran lalu lintas pembayaran. Disamping itu, bank juga sebagai suatu industri yang dalam kegiatan usahanya mengandalkan kepercayaan masyarakat sehingga seharusnya tingkat kesehatan bank perlu dipelihara (Merkusiwati, 2007).

Berdasarkan pasal 5 Undang-Undang No 10 Tahun 1998, tentang Perbankan, terdapat 2 jenis bank, yaitu Bank Umum dan Bank Perkreditan Rakyat. Kedua jenis bank tersebut dalam menjalankan kegiatan usahanya diklasifikasikan menjadi dua, yaitu bank konvensional dan bank dengan prinsip syariah. Perbedaan mendasar 
antara bank konvensional dan bank syariah adalah adanya larangan bunga dalam bank syariah sebagaimana sistem bunga yang dianut oleh bank konvensional. Sehingga dalam menjalankan kegiatan operasinya, bank syariah menganut sistem bagi hasil.

Perkembangan Bank Syariah di Indonesia sangat pesat dan baik walaupun berjalan dengan lambat. Hal ini terbukti dengan pertumbuhan aset tiap tahunnya bertambah. Tahun 2011 aset perbankan syariah di Indonesia tumbuh 50,1 persen. Aset sebesar Rp 101,2 triliun pada Maret 2011, menjadi Rp 151,9 triliun pada Maret 2012. Dana pihak ketiga juga tumbuh 50 persen, dari Rp 79,65 triliun pada Maret 2011, menjadi Rp 119,6 triliun pada Maret 2012. Data ini dipaparkan oleh Direktur Eksekutif Perbankan Syariah Bank Indonesia, Edy Setiadi bahwa data tersebut merupakan gabungan bank umum syariah, unit usaha syariah, dan bank perkreditan rakyat syariah.

Peningkatan eksistensi bank syariah di Indonesia didorong oleh tingginya minat masyarakat untuk menempatkan dananya di bank syariah dan telah berkembang menjadi sebuah tren. Dalam Laporan Perkembangan Perbankan Syariah, berkembangnya tren tersebut dikarenakan produk dana perbankan syariah memiliki daya tarik bagi deposan mengingat nisbah bagi hasil dan margin produk tersebut masih kompetitif dibanding bunga di bank konvensional. Selain itu, kinerja perbankan syariah menunjukan peningkatan yang signifikan tercermin dari permodalan dan profitabilitas yang semakin meningkat (LPPS, 2010). Kinerja bank merupakan hal yang paling penting, karena bisnis perbankan adalah bisnis kepercayaan, sehingga bank harus menunjukkan kredibilitasnya agar masyarakat banyak melakukan transaksi di bank tersebut, salah satunya dalam peningkatan profitabilitas. Peningkatan laba bank syariah tidak saja berpengaruh terhadap tingkat bagi hasil untuk para pemegang saham tetapi juga berpengaruh terhadap hasil yang diberikan kepada nasabah penyimpan dana. Oleh karena itu, bank syariah memiliki peranan penting untuk terus meningkatkan profitabilitasnya.

Profitabilitas sebagai salah satu acuan dalam mengukur besarnya laba menjadi begitu penting untuk mengetahui apakah perusahaan telah menjalankan usahanya secara efisien. Efisiensi sebuah usaha baru dapat diketahui setelah membandingkan laba yang diperoleh dengan aktiva atau modal yang menghasilkan laba tersebut. Menurut Karya \& Rakhman, tingkat profitabilitas bank syariah di Indonesia merupakan yang terbaik di dunia diukur dari rasio laba terhadap aset $(R O A)$. Profitabilitas juga mempunyai arti penting dalam usaha mempertahankan kelangsungan hidupnya dalam jangka panjang, karena profitabilitas menunjukkan apakah badan usaha tersebut mempunyai prospek yang baik di masa yang akan datang. Dengan demikian setiap badan usaha akan selalu berusaha meningkatkan profitabilitasnya, karena semakin tinggi tingkat profitabilitas suatu badan usaha maka kelangsungan hidup badan usaha tersebut akan lebih terjamin.

Return on Assets (ROA) memfokuskan pada kemampuan perusahaan untuk memperoleh pendapatan dalam operasi perusahaan. $R O A$ digunakan untuk mengukur profitabilitas bank karena Bank Indonesia sebagai pembina dan pengawas perbankan lebih mengutamakan nilai profitabilitas suatu bank yang diukur dengan aset yang dananya sebagian besar dari dana simpanan masyarakat. Selain itu ROA digunakan untuk mengukur efektivitas perusahaan di dalam menghasilkan keuntungan dengan memanfaatkan aktiva yang dimilikinya.

Penelitian tentang rasio keuangan dan pengaruhnya terhadap profitabilitas bank di Indonesia telah

Jurnal Akuntansi Indonesia 
dilakukan oleh beberapa peneliti. Banyak perbedaan penelitian riset GAP salah satunya Hesti (2002) dan Adi Setiawan (2009) meneliti CAR yang menunjukkan pengaruh positif terhadap profitabilitas bank, peneliti satunya Sintia Tri Furi (2005) meneliti bahwa CAR menunjukkan adanya pengaruh negatif terhadap profitabilitas bank. Menurut Diah Aristya (2010) CAR tidak berpengaruh terhadap profitabilitas bank. Adi Setiawan (2009) meneliti NPF menunjukkan pengaruh negatif terhadap profitabilitas bank. Shintia Tri Furi (2005) meneliti bahwa rasio ini menunjukkan pengaruh positif terhadap profitabilitas bank, sedangkan oleh Budi Ponco (2008) menunjukkan tidak adanya pengaruh rasio ini terhadap profitabilitas bank. Peneliti oleh Alfian Indrawan (2009) mengenai Rasio Biaya Operasional terhadap Pendapatan Operasional (BOPO) menunjukkan adanya pengaruh yang positif terhadap profitabilitas bank syariah. Peneliti berikutnya Budi Ponco (2008) dan Adi Setiawan (2009) meneliti bahwa rasio biaya operasional terhadap pendapatan operasional menunjukkan adanya pengaruh negatif pada profitabilitas bank syariah. Adi Setiawan (2009) mengenai FDR menunjukkan adanya pengaruh positif antara FDR terhadap profitabilitas bank. Menurut Siti Nurkhosidah (2010) dan Yuliani (2007) meneliti FDR bahwa rasio menunjukkan hasil yang tidak berpengaruh signifikan terhadap profitabilitas bank.

Berdasarkan uraian diatas, penelitian ini ingin mengetahui seberapa besar pengaruh faktor-faktor seperti permodalan (CAR), likuiditas (FDR), kualitas aktiva (NPF), dan earning (BOPO) terhadap profitabilitas (ROA) Bank syariah di Indonesia selama tahun 2009 sampai 2012.

\section{KERANGKA TEORITIS DAN PENGEMBANGAN HIPOTESIS}

\section{Profitabilitas}

Profitabilitas adalah kemampuan suatu perusahaan untuk dalam menghasilkan laba selama periode tertentu. Imam Gozali (2006) mendefinisikan profitabilitas sebagai dasar dari adanya keterkaitan antara efisiensi operasional dengan kualitas jasa yang dihasilkan oleh suatu bank (Riyanto, 2001:35).

Menurut Hasan (2003) bahwa profitabilitas merupakan ukuran spesifik dari performance sebuah bank, dimana ia merupakan tujuan dari manajemen perusahaan dengan memaksimalkan nilai dari para pemegang saham, optimalisasi dalam berbagai tingkat return, dan meminimalisir resiko yang ada. Lukman Dendawijaya (2009:119) menjelaskan ROA digunakan untuk mengukur profitabilitas bank karena Bank Indonesia sebagai pembina dan pengawas perbankan lebih mengutamakan nilai profitabilitas suatu bank, diukur dengan menggunakan asset yang dananya sebagian besar dari dana simpanan masyarakat. Sehingga disimpulkan bahwa profitabilitas adalah kemampuan suatu perusahaan untuk menghasilkan laba selama periode tertentu. Profitabilitas juga dapat diartikan sebagai ukuran spesifik performa sebuah bank dimana merupakan tujuan dari manajemen perusahaan dengan memaksimalkan nilai perusahaan dimata para pemegang saham, optimalisasi nilai return pada setiap operasional perusahaan, dan meminimalisasi tingkat resiko yang ada.

Bank syariah juga merupakan lembaga keuangan yang berorientasi pada laba (profit oriented). Pengertian profitabilitas dari sudut pandang bank syariah bahwa laba bukan hanya untuk kepentingan pemilik atau pendiri, tetapi juga untuk pengembangan usaha. Dalam rangka meningkatkan profitabilitasnya bank syariah menempatkan dana yang telah dihimpun dalam bentuk kredit atau pembiayaan, baik bersifat jangka pendek maupun jangka panjang. 


\section{Pengembangan Hipotesis \\ Pengaruh CAR Terhadap ROA}

Menurut Mudrajad Kuncoro dan Suhardjono (2002) CAR adalah rasio yang digunakan untuk mengukur kemampuan bank dalam mempertahankan modal yang mencukupi dan kemampuan bank dalam mengidentifikasi, mengukur, mengawasi, dan mengontrol risiko-risiko yang timbul yang dapat berpengaruh terhadap besarnya modal bank.

Menurut Lisa dan Suryani (2006) jika nilai CAR tinggi berarti bank tersebut mampu membiayai operasi bank, keadaan yang menguntungkan bank tersebut akan memberikan kontribusi yang cukup besar bagi profitabilitas.

Berdasarkan Lampiran 14 Surat Edaran Bank Indonesia Nomor: 3/30/DPNP ada dua rasio keuangan yang dapat digunakan untuk menilai aspek permodalan yaitu CAR (Capital Adequacy Ratio) dan Aktiva Tetap terhadap Modal. Rasio yang sering digunakan adalah CAR atau rasio modal terhadap ATMR (Aktiva Tertimbang Menurut Risiko) yang didapatkan dengan membandingkan antara modal dengan ATMR. Modal sendiri bank syariah terdiri dari modal inti ditambah modal pelengkap. Modal inti terdiri atas modal disetor, modal sumbangan, cadangan-cadangan yang dibentuk dari laba setelah pajak. Modal pelengkap terdiri dari cadangan-cadangan yang dibentuk tidak berasal dari laba dan modal pinjaman.

ATMR terdiri dari Market Risk, Credit Risk, Operational Risk. Market Risk merupakan resiko kerugian dari posisi dalam on dan off balance sheet yang timbul karena perubahan faktor pasar (suku bunga dan nilai tukar). Credit Risk merupakan resiko kerugian karena debitur gagal memenuhi kewajibannya sesuai perjanjian yang disepakati. Operational Risk merupakan resiko kerugian langsung maupun tidak langsung yang disebabkan faktor kelemahan atau kegagalan proses internal, SDM, sistem dan kejadian eksternal.Pada bank syariah perhitungan ATMR sedikit berbeda dari bank konvensional. Aktiva pada bank syariah dibagi atas aktiva yang dibiayai dengan modal sendiri serta aktiva yang didanai oleh rekening bagi hasil.Aktiva yang didanai oleh modal sendiri dan hutang risikonya ditanggung modal sendiri, sedangkan yang didanai oleh rekening bagi hasil risikonya ditanggung oleh rekening bagi hasil itu sendiri.

Dapat ditarik kesimpulan bahwa CAR merupakan rasio yang memperlihatkan seberapa besar jumlah seluruh aktiva bank yang mengandung risiko (kredit, penyertaan, surat berharga, tagihan pada bank lain) ikut dibiayai dari modal sendiri disamping memperoleh dana-dana dari sumber di luar bank. Semakin besar nilai CAR maka semakin sehat bank tersebut karena akan semakin besar daya tahan bank yang bersangkutan dalam menghadapi penyusutan nilai harta bank yang timbul karena adanya harta bermasalah. Sesuai dengan peraturan Bank Indonesia No 9/13/PBI/2007, nilai batas minimum CAR yang baik adalah 8\%. Jika nilai CAR suatu perusahaan berada dibawah $8 \%$ maka perusahaan tersebut tidaklah sehat.

\section{H1 : CAR berpengaruh positif terhadap ROA.}

\section{Pengaruh FDR Terhadap ROA}

Menurut Arthesa (2009) FDR merupakan rasio yang digunakan untuk mengukur likuiditas suatu bank dalam membayar kembali penarikan dana yang dilakukan deposan dengan mengandalkan kredit yang 
diberikan sebagai sumber likuiditasnya, yaitu dengan cara membagi jumlah kredit yang diberikan oleh bank terhadap dana pihak ketiga. Dengan penyaluran dana pihak ketiga yang besar maka pendapatan bank (ROA) akan semakin meningkat sehingga FDR berpengaruh positif terhadap ROA (Gelos,2006).

FDR dalam dunia perbankan syariah melakukan pembiayaan dengan tidak menggunakan sistem bunga. FDR menyatakan seberapa jauh kemampuan bank dalam membayar kembali penarikan dana yang dilakukan deposan dengan mengandalkan kredit yang diberikan sebagai sumber likuiditasnya. Semakin besar kredit maka pendapatan yang diperoleh naik, karena pendapatan naik maka otomatis laba juga akan meningkat. Sesuai dengan Surat Edaran Bank Indonesia No 6/23/DPNP, batas minimal nilai FDR yang baik adalah $80 \%$.

\section{H2 : FDR berpengaruh positif terhadap ROA.}

\section{Pengaruh NPF Terhadap ROA}

Menurut Muhammad (2005:359) mendefinisikan risiko pembiayaan yang diterima bank merupakan salah satu risiko usaha bank, yang diakibatkan dari tidak dilunasinya kembali pinjaman yang diberikan atau investasi yang sedang dilakukan oleh pihak bank.

Pengelolaan pembiayaan sangat diperlukan oleh bank, mengingat fungsi pembiayaan sebagai penyumbang pendapatan terbesar bagi bank syariah dan juga tingkat kesehatan pembiayaan (NPF) ikut mempengaruhi pencapaian laba bank (Suhada, 2009).

Non Performing Financing (NPF) yang analog dengan Non Performing Loan (NPL) pada bank konvensional merupakan rasiokeuangan yang bekaitan dengan risiko kredit. Non Performing Financing menunjukan kemampuan manajemen bank dalam mengelola pembiayaan bermasalah yang diberikan oleh bank. Sehingga semakin tinggi rasio ini maka akan semakin semakin buruk kualitas kredit bank yang menyebabkan jumlah kredit bermasalah semakin besar maka kemungkinan suatu bank dalam kondisi bermasalah semakin besar. Kredit dalam hal ini adalah kredit yang diberikan kepada pihak ketiga tidak termasuk kredit kepada bank lain. Kredit bermasalah adalah kredit dengan kualitas kurang lancar,diragukan dan macet.

\section{H3 : NPF berpengaruh negatif terhadap ROA.}

\section{Pengaruh BOPO Terhadap ROA}

Menurut Lukman (2000:120) mendefinisikan Rasio biaya operasional adalah perbandingan antara biaya operasional dan pendapatan operasional. Rasio ini digunakan untuk mengukur tingkat efisiensi dan kemampuan dalam melakukan operasi.

Berdasarkan lampiran 14 Surat Edaran Bank Indonesia Nomor : 3/30/DPNP ada empat rasio keuangan yang dapat digunakan yaitu : ROA (Return on Assets), ROE (Return on Equity), NIM (Net Interest Margin), dan BOPO (biaya Operasional terhadap Pendapatan Operasional). Rasio yang paling sering digunakan anara lain ROA, $R O E$, dan BOPO.

BOPO (Biaya Operasional pada Pendapatan Operasional) adalah rasio yang menunjukan tingkat efisiensi dan kinerja operasional bank. Rasio ini mengukur kemampuan bank dalam mengendalikan biaya operasionalnya terhadap pendapatan operasional. Semakin kecil rasio ini maka semakin efisien bank dalam 
menggunakan biaya operasionalnya. BOPO dihitung dengan membandingkan total biaya operasionalnya dengan total pendapatan operasional. Nilai BOPO yang baik berkisar antara 75\% hingga 90\%. Jika suatu perusahaan mempunyai nilai BOPO diatas $90 \%$ maka perusahaan tersebut tidak sehat karena beban operasional perusahaan yang tidak diimbangi dengan baik oleh pendapatan operasionalnya.

\section{H4 : BOPO berpengaruh negatif terhadap ROA.}

\section{Pengaruh REO Terhadap ROA}

Penilaian aspek efisiensi dimaksudkan untuk mengukur kemampuan bank dalam memanfaatkan dana yang dimiliki dan biaya yang dilakukan untuk mengoperasikan dana tersebut. Efisiensi operasional berarti biaya yang dikeluarkan untuk menghasilkan keuntungan, lebih kecil daripada keuntungan yang diperoleh dari penggunaan aktiva tersebut. Rasio Biaya Operasional terhadap Pendapatan Operasional sering disebut Rasio Efisiensi digunakan untuk mengukur kemampuan manajemen bank dalam mengendalikan biaya operasional terhadap pendapatan operasional. Semakin kecil rasio ini berarti semakin efisien biaya operasional yang dikeluarkan bank yang bersangkutan (Yuliani, 2007).

Efisiensi operasional bank syariah diukur menggunakan Rasio Efisiensi Operasional (REO) yaitu perbandingan antara biaya operasional bank dengan pendapatan operasional (Muhammad,2009).

Menurut Bank Indonesia (SE. Intern BI, 2004), efisiensi operasi diukur dengan membandingkan total biaya operasi dengan total pendapatan operasi. Rasio ini bertujuan untuk mengukur kemampuan pendapatan operasional dalam menutup biaya operasional. Rasio yang semakin meningkat mencerminkan kurangnya kemampuan bank dalam menekan biaya operasional dan meningkatkan pendapatan operasionalnya yang dapat menimbulkan kerugian karena bank kurang efisien dalam mengelola usahanya (Budi Ponco, 2008).

Tingkat efisiensi bank dalam menjalankan operasinya, berpengaruh terhadap tingkat pendapatan yang dihasilkan oleh bank. Jika kegiatan operasional dilakukan dengan efisien maka pendapatan yang dihasilkan bank tersebut akan naik. Sehingga semakin besar rasio efisiensi, maka akan semakin menurun kinerja keuangan perbankan. Begitu juga sebaliknya, bila rasio biaya operasional terhadap pendapatan operasional semakin kecil, maka dapat disimpulkan bahwa profitabilitas suatu perusahaan (perbankan) semakin meningkat (Budi Ponco, 2008). Hal ini juga didukung oleh penelitian dari (Adi Setiawan, 2009) dan (Yuliani, 2007) yang dalam hasil penelitiannya meyatakan semakin efisien kinerja operasional suatu bank maka keuntungan yang diperoleh akan semakin besar.

Berdasarkan ketentuan Bank Indonesia, batas rasio ini adalah 92\% - 93,52\%. Biaya Operasional adalah keseluruhan total biaya operasional ditambah dengan biaya non operasional. Biaya operasional terdiri dari biaya tenaga kerja, biaya administrasi, biaya penyisihan penghapusan aktiva produktif, dan biaya lainnya. Yang termasuk biaya non operasional meliputi kerugian pelepasan aktiva tetap, beban lainnya, dan zakat.

H5 : BOPO berpengaruh negatif terhadap ROA. 


\section{JURNAL AKUNTANSI INDONESIA}

\section{METODE PENELITIAN}

\section{Populasi dan Sampel}

Populasi yang digunakan dalam penelitian ini adalah bank umum syariah yang terdaftar di Bank Indonesia pada tahun 2009-2012. Sampel penelitian ini adalah perbankan syariah yang tercantum di Bank Indonesia, dipilih dengan menggunakan purposive sampling method dengan kriteria sebagai berikut :

1. Bank Syariah merupakan Bank Umum Syariah (BUS) yang terdiri dari 11 bank di Indonesia.

2. Bank Syariah membuat laporan keuangan pada periode 2009-2012 dan telah dipublikasikan di Bank Indonesia.

3. Data yang dibutuhkan untuk penelitian tersedia selama periode 2009-2012.

\section{Definisi Operasional Variabel dan Pengukuran Variabel}

Definisi operasional variabel dan pengukuran variabel dalam penelitian ini adalah sebagai berikut :

1. Capital Adequacy Ratio(CAR)

Rasio untuk mengukur kecukupan modal bank syariah yaitu dengan menggunakan rasio Capital Adequacy Ratio (Muhammad, 2009). Capital Adequancy Ratio (CAR) adalah rasio yang memperlihatkan seberapa besar jumlah seluruh aktiva bank yang mengandung unsur risiko (kredit, penyertaan, surat berharga, tagihan pada bank lain) yang ikut dibiayai dari modal sendiri disamping memperoleh dana-dana dari sumber-sumber diluar bank (Yuliani, 2007).Secara fomula ditunjukan dengan:

$$
C A R=\frac{\text { Jumlah Modal Sendiri (modal inti }+ \text { modal pelengkap) }}{\text { Jumlah ATMR (neraca aktiva }+ \text { neraca administrasi) }}
$$

2. Financing to Deposit Ratio(FDR)

Rasio yang digunakan untuk mengukur likuiditas suatu bank yang dengan cara membagi jumlah kredit yang diberikan oleh bank terhadap dana pihak ketiga. Secara formula ditunjukan dengan:

$F D R=\frac{\text { Total Kredit Pembiayaan }}{\text { Total Dana Pihak Ketiga }}$

3. Non Performing Financing(NPF)

Non Performing Financing menunjukan kemampuan manajemen bank dalam mengelola pembiayaan bermasalah yang diberikan oleh bank. Rasio NPF ini dapat dirumuskan sebagai berikut:

$N P F=\frac{\text { Pembiayaan }(\mathrm{KL}, \mathrm{D}, \mathrm{M})}{\text { Total Pembiayaan }}$

Keterangan :

NPF $\quad=$ Non Performing Financing

Pembiayaan KL = Pembiayaan Kurang Lancar

Pembiayaan D = Pembiayaan Diragukan

Pembiayaan M = Pembiayaan Macet 
4. Biaya Operasional terhadap Pendapatan Operasional (BOPO)

Rasio BOPO digunakan untuk mengukur kemampuan manajemen bank dalam mengendalikan biaya operasional terhadap pendapatan operasional. Secara formula ditunjukan dengan:

$$
\text { BOPO }=\frac{\text { Total Beban Operasional }}{\text { Total Pendapatan Operasional }}
$$

5. Rasio Efisiensi Operasional (REO)

Rasio ini digunakan untuk mengukur kemampuan manajemen bank dalam mengendalikan biaya operasional terhadap pendapatan operasional. Rasio ini dirumuskan sebagai berikut:

REO $=\frac{\text { Total Biaya (By. Operasional }+ \text { By. Non Operasional) }}{\text { Total Pndptn (Pndptn Operasional }+ \text { Pndptn Non Operasional) }}$

6. Return On Assets (ROA)

Profitabilitas diukur dari rasio laba terhadap aset atau biasa disebut ROA. Secara formula ditunjukkan dengan rumus:

$R O A=\frac{\text { Laba sebelum pajak }}{\text { Rata }- \text { rata total aset }}$

\section{Teknik Analisis Data}

Dalam penelitian ini metode analisis yang digunakan antara lain :

1. Statistik Deskriptif

2. Statistik diskriptif merupakan alat statistik yang berfungsi mendeskripsikan atau memberi gambaran terhadap objek yang diteliti melalui data sampel atau populasi sebagaimana adanya, tanpa melakukan analisis dan membuat kesimpulan yang berlaku umum dari data tersebut. Statistik deskriptif digunakan untuk mendiskripsi suatu data yang dilihat dari mean, median, deviasi standar, nilai minimum, dan nilai maksimum.

3. Uji Asumsi Klasik

Sebelum melakukan pengujian hipotesis dengan menggunakan analisis regresi linier berganda perlu dilakukan terlebih dahulu pengujian asumsi klasik. Uji asumsi klasik meliputi:
a. Uji Normalitas
b. Uji Multikolinieritas
c. Uji Autokorelasi
d. Uji Heteroskedastisitas

4. Metode Regresi Linier Berganda

Regresi linier berganda yaitu suatu model linier regresi yang variabel dependennya merupakan fungsi linier 
dari beberapa variabel bebas. Hubungan fungsi antara satu variabel dependen dengan lebih dari satu variabel independen dapat dilakukan dengan model regresi berganda, dimana profitabilitas (ROA) sebagai variabel dependen, sedangkan variabel independennya meliputi CAR, NPF, FDR, BOPO, dan REO. Persamaannya:

$$
Y=a+b 1 X 1+b 2 X 2+b 3 \times 3+b 4 X 4+b 5 X 5+e \ldots
$$

5. Pengujian Hipotesis

Secara statistik, ketepatan fungsi regresi sampel dalam menaksir nilai aktual dapat diukur dengan nialai statistik t, nilai statistik f, serta koefisien deteminasi.

\section{HASIL DAN PEMBAHASAN}

\section{Deskriptif Objek Penelitian}

Objek penelitian yang digunakan adalah laporan keuangan Perbankan Syariah yang dipublikasikan dalam statistik Perbankan Syariah tahun 2009-2012 dalam periode bulanan. Penelitian ini melihat pengaruh CAR, NPF, FDR, BOPO, dan REO terhadap Profitabilitas (ROA) pada Bank Syariah di Indonesia periode 20092012. Jumlah data yang digunakan sebanyak 48 data untuk masing-masing variabel penelitian.

Tabel 1 berikut ini menampilkan karakteristik sampel yang digunakan di dalam penelitian ini meliputi jumlah sampel (N), rata-rata sampel (rata-rata), nilai maksimum, nilai minimum serta standar deviasi untuk masing-masing variabel.

Nilai rata-rata dari CAR adalah $12,62 \%$ dengan standar deviasi 4,90\%. Nilai CAR tertinggi adalah 20,23\% sedangkan nilai terendah adalah 3,83\%. Nilai rata-rata dari FDR adalah 95,24\% dengan standar deviasi 8,13\%. Nilai FDR tertinggi adalah $103,33 \%$ sedangkan nilai terendah adalah $47,74 \%$. Nilai rata-rata dari NPF adalah $3,86 \%$ dengan standar deviasi $0,97 \%$. Nilai NPF tertinggi adalah 5,90\% sedangkan nilai terendah adalah $2,42 \%$. Nilai rata-rata dari REO adalah 0,74\% dengan standar deviasi 0,11\%. Nilai REO tertinggi adalah 0,91\% sedangkan nilai terendah adalah 0,59\%. Nilai rata-rata dari BOPO adalah 81,4\% dengan standar deviasi 8,03\%. Nilai BOPO tertinggi adalah 98,39\% sedangkan nilai terendah adalah 67,61\%. Nilai rata-rata dari ROA adalah $1,86 \%$ dengan standar deviasi 0,29\%. Nilai ROA tertinggi adalah 2,44\% sedangkan nilai terendah adalah 1,25\%.

Dari data yang diperoleh setelah semua asumsi klasik terpenuhi kemudian dianalisis dengan metode regresi linier berganda dan dihitung dengan menggunakan program SPSS versi 17,0. Berdasar output SPSS tersebut secara parsial pengaruh dari ketiga variabel independen yaitu pertumbuhan perusahaan, ukuran perusahaan, dan laba terhadap CAR ditunjukkan pada Tabel 2.

Dengan melihat Tabel 2 di atas, dapat disusun persamaan regresi linear berganda sebagai berikut:

$$
\mathrm{ROA}=4,323+0,026 \mathrm{CAR}+0,009 \mathrm{FDR}-0,042 \mathrm{NPF}-1,530 \mathrm{REO}-0,029 \mathrm{BOPO}+\mathrm{e}
$$

Persamaan regresi ini mempunyai makna sebagai berikut: Nilai konstanta sebesar 4,323; menunjukkan bahwa nilai ROA bank syariah di Indonesia adalah 4,323\% bila tidak dipengaruhi oleh variabel-variabel independen (CAR, FDR, NPF, REO, dan BOPO). Nilai koefisienregresi variabel CAR adalah sebesar 0,026. Tanda 
koefisien regresi yang positif ini menunjukkan setiap ada peningkatan 100\% CAR akan mengakibatkan meningkatnya ROA sebesar 2,6\% ketika pengaruh variabel lain adalah konstan.

1. Nilai koefisienregresi variabel FDR adalah sebesar 0,009. Tanda koefisien regresi yang positif ini menunjukkan setiap ada peningkatan 100\% FDR akan mengakibatkan meningkatnya ROA sebesar 0,9\% ketika pengaruh variabel lain adalah konstan.

2. Nilai koefisienregresi variabel NPF adalah sebesar -0,042. Tanda koefisien regresi yang negatif ini menunjukkan setiap ada peningkatan 100\% NPF akan mengakibatkan turunnya ROA sebesar 4,2\% ketika pengaruh variabel lain adalah konstan.

3. Nilai koefisienregresi variabel REO adalah sebesar -1,530. Tanda koefisien regresi yang negatif ini menunjukkan setiap ada peningkatan 100\% REO akan mengakibatkan turunnya ROA sebesar 153\% ketika pengaruh variabel lain adalah konstan.

4. Nilai koefisienregresi variabel BOPO adalah sebesar -0,029. Tanda koefisien regresi yang negatif ini menunjukkan setiap ada peningkatan 100\% BOPO akan mengakibatkan turunnya ROA sebesar 2,9\% ketika pengaruh variabel lain adalah konstan.

\section{Uji Asumsi Klasik}

a. Uji Normalitas

Uji normalitas penelitian ini dilakukan dengan uji grafik normal probability plot yang hasilnya terlihat pada Gambar 1 berikut :

- Gambar 1

Sumber : data sekunder yang diolah, 2014

Berdasarkan hasil gambar di atas, maka dapat disimpulkan bahwa data menyebar di sekitar garis diagonal dan mengikuti arah garis diagonal, maka model regresi memenuhi asumsi normalitas.

b. Uji Multikolinieritas

Uji multikolinieritas dilakukan untuk menguji apakah pada model regresi ditemukan adanya korelasi antar variabel independen. Hasil pengujian multikolinearitas adalah:

Tabel 5

Sumber : data sekunder yang diolah, 2014

Hasil perhitungan pada tabel diatas bahwa semua variabel bebas memiliki nilai tolerance lebih dari 0,1 dan nilai VIF kurang dari 10, hal ini menunjukkan tidak terdapat korelasi antar variabel bebas, atau model regresi dalam penelitian ini bebas dari gejala multikolinieritas.

c. Uji Heteroskedastisitas

Pengujian heterokedastisitas dapat dilakukan dengan menggunakan Scatter Plot. Hasil pengujian heteroskedastisitas adalah sebagai berikut: Gambar 2

Sumber : data sekunder yang diolah, 2014

Dari grafik scatterplot pada Gambar 2 terlihat bahwa titik-titik menyebar secara acak baik di atas maupun 
di bawah angka 0 pada sumbu $Y$, dapat disimpulkan bahwa model regresi dalam penelitian ini tidak memgalami heteroskedastisitas.

d. Uji Autokorelasi

Uji autokorelasi dilakukan dengan uji mapping Durbin Watson (DW). Hasil uji DW untuk kedua model regresi dalam penelitian ini terlihat pada Tabel 6 sebagai berikut:

Tabel 6

Sumber : data sekunder yang diolah, 2014

Maka diperoleh nilai hitung DW $(\mathrm{d})=1,227$; nilai d-tabel untuk model regresi dengan jumlah data $(\mathrm{N})$ 48, dan $\mathrm{k}=5$ adalah : $\mathrm{dl}=1,164$; $\mathrm{du}=1,587 ; 4-\mathrm{du}=2,413$; dan 4-dl = 2,836; maka dari perhitungan ini disimpulkan bahwa d-test terletak pada daerah uji. Dapat dilihat pada Gambar 3 sebagai berikut:

Gambar 3

Sumber : data sekunder yang diolah, 2014

Berdasarkan gambar di atas menunjukkan bahwa model regresi berada di daerah ragu-ragu atau di daerah autokorelasi positif karena d-hitung berada diantara dl dan du. Untuk itu dilakukan upaya mengatasi gejala autokorelasi dengan menambahkan satu variabel lag, yang hasil nya dilihat pada Tabel 7 sebagai berikut:

Tabel 7

Sumber : data sekunder yang diolah, 2014

Melalui penambahan 1 variabel lag (Lag_ROA) Nilai DW menjadi 1,752; nilai ini berada diantara nilai du dan 4 - du atau berada di antara 1,639 dan 2,361 untuk $\mathrm{N}=47$ dan $\mathrm{k}=6$ sehingga disimpulkan bahwa model regresi ini bebas dari gejala autokorelasi.

\section{Model Persamaan Regresi Berganda} - Tabel 8

Sumber : Data sekunder yang diolah, 2014

\section{Pengujian Hipotesis}

Pengujian koefisien regresi parsial atau uji t untuk mengetahui apakah variabel independen secara individual mempengaruhi variabel dependen.

a. Pengaruh CAR Terhadap ROA

Penelitian ini berbunyi bahwa CAR berpengaruh positif terhadap ROA. Hasil uji regresi linier berganda pada variabel CAR terhadap ROA menghasilkan koefisien regresi sebesar 0,026 dengan signifikansi sebesar 0,024; karena tingkat signifikansi dibawah 0,05; maka dinyatakan bahwa hipotesis pertama penelitian ini diterima yaitu adalah benar bahwa CAR berpengaruh positif terhadap ROA.

b. Pengaruh FDR Terhadap ROA

Penelitian ini berbunyi bahwa FDR berpengaruh negatif terhadap ROA. Hasil uji regresi linier berganda pada variabel FDR terhadap ROA menghasilkan koefisien regresi sebesar 0,009 dengan signifikansi sebesar 
0,007; karena tingkat signifikansi dibawah 0,05; maka dinyatakan bahwa hipotesis kedua penelitian ini diterima yaitu adalah benar bahwa FDR berpengaruh positif terhadap ROA.

c. Pengaruh NPF Terhadap ROA

Penelitian ini berbunyi bahwa NPF berpengaruh negatif terhadap ROA. Hasil uji regresi linier berganda pada variabel NPF terhadap ROA menghasilkan koefisien regresi sebesar 0,042 dengan signifikansi sebesar 0,368; karena tingkat signifikansi lebih dari 0,05; maka dinyatakan bahwa hipotesis ketiga penelitian ini ditolak yaitu NPF tidak berpengaruh negatif terhadap CAR.

d. Pengaruh BOPO Terhadap ROA

Penelitian ini berbunyi bahwa BOPO berpengaruh negatif terhadap ROA. Hasil uji regresi linier berganda pada variabel BOPO terhadap ROA menghasilkan koefisien regresi sebesar -1,53 dengan signifikansi sebesar 0,000; karena tingkat signifikansi dibawah 0,05; maka dinyatakan bahwa hipotesis kelima penelitian ini diterima yaitu adalah benar bahwa BOPO berpengaruh negatif terhadap ROA.

e. Pengaruh REO Terhadap ROA

Penelitian ini berbunyi bahwa REO berpengaruh negatif terhadap ROA. Hasil uji regresi linier berganda pada variabel REO terhadap ROA menghasilkan koefisien regresi sebesar -1,53 dengan signifikansi sebesar 0,000; karena tingkat signifikansi dibawah 0,05; maka dinyatakan bahwa hipotesis keempat penelitian ini diterima yaitu adalah benar bahwa REO berpengaruh negatif terhadap ROA.

\section{Uji Simultan (Uji F)}

Hasil perhitungan uji F ini dapat dilihat pada Tabel 9 berikut: Tabel 9

Sumber : Data sekunder yang diolah, 2014

Nilai $\mathrm{F}$ hitung yang dihasilkan adalah sebesar 17,893 dengan probabilitas 0,000; karena probabilitas lebih kecil dari tingkat signifikansi yang digunakan yaitu 5\%, maka model regresi dapat digunakan untuk memprediksi profitabilitas bank (ROA) atau dapat dikatakan bahwa variabel bebas yang meliputi CAR, FDR, NPF, REO, dan BOPO secara bersama-sama berpengaruh terhadap profitabilitas bank (ROA).

\section{Koefisien Determinasi ( $\left.\mathbf{R}^{2}\right)$}

Hasil perhitungan koefisien determinasi penelitian ini dapat terlihat pada Tabel 10 berikut: Tabel 10

Sumber : Data sekunder yang diolah, 2014

Berdasar output SPSS tampak bahwa dari hasil perhitungan diperoleh nilai koefisien determinasi (adjusted $R^{2}$ ) sebesar 0,642. Hal ini menunjukkan bahwa besar pengaruh variabel independen yaitu CAR, FDR, NPF, REO, dan BOPO terhadap variabel dependen profitabilitas bank (ROA) adalah sebesar $64,2 \%$ sedangkan sisanya sebesar 35,8\% dipengaruhi oleh faktor-faktor lain yang tidak dimasukkan dalam model regresi. 


\section{Simpulan}

Berdasarkan hasil penelitian dan pembahasan yang telah dilakukan, dapat disimpulkan bahwa: 1) CAR berpengaruh positif terhadap ROA, artinya tinggi atau rendahnya CAR dapat memprediksi tinggiatau rendahnya ROA. 2) FDR berpengaruh positif terhadap ROA, artinya tinggi atau rendahnya FDR dapat memprediksi tinggi atau rendahnya ROA. 3) NPF tidak berpengaruh negatif terhadap ROA, karena nilai rata-rata NPF bank syariah di Indonesia dalam penelitian tergolong masih rendah sehingga diasumsikan bahwa tingkat kredit macetnya juga rendah dan tidak sampai berefek terhadap laba bank syariah. 4) REO berpengaruh negatif terhadap ROA, artinya tingginya REO dapat memprediksi rendahnya ROA, demikian sebaliknya rendahnya REO dapat memprediksi tingginya ROA. 5) BOPO berpengaruh negatif terhadap ROA, artinya tingginya BOPO dapat memprediksi rendahnya ROA, demikian sebaliknya rendahnya BOPO dapat memprediksi tingginya ROA.

\section{Implikasi dan Keterbatasan.}

Ada beberapa implikasi penting yang bisa diambil dari penelitian ini. Hasil penelitian ini akan memberikan beberapa kontribusi potensial. Penelitian selanjutnya diharapkan bisa meneliti faktor-faktor lain yang mempengaruhi tingkat profitabilitas bank. Mengingat penelitian kali ini hanya menggunakan 5 variabel penjelas, dan juga dapat memperpanjang periode amatan, sehingga hasil yang akan didapatkan memiliki keakuratan yang tinggi.

Sebagaimana yang diuraikan di atas bahwa hasil penilitian ini terbatas pada pengamatan yang relatif pendek. Selain itu, penlitian ini hanya meneliti pengaruh variabel independen (CAR, NPF, FDR, BOPO, dan REO) terhadap variabel dependen (ROA) tanpa meneliti lebih jauh penyebab lainnya dari variabel yang sudah diteliti.

\section{DAFTAR PUSTAKA}

Arditya Prayudi.2011."Pengaruh CAR, NPL, ROA, NIM terhadap LDR". http://gunadarma.ac.id.

Bambang Agus P.2010."Faktor-faktor yang berpengaruh terhadap tingkat profitabilitas Bank Umum Syariah". Jurnal akuntansi, manajemen bisnis dan sektor publik (JAMBSP). Vol.7, No.1 Oktober 2010: 63-79.

Bank Indonesia Direktorat Perbankan Syariah.2011.Laporan Perkembangan Perbankan Syariah.Jakarta. Indonesia.

Bank Indonesia Direktorat Perbankan Syariah.2012.Laporan Perkembangan Perbankan Syariah.Jakarta. Indonesia.

Bank Indonesia.2011.Data Statistik. http: //www.bi.go.id /biweb/ Templates/ Dynamic/DataStatCatID.aspx.

Dhika Rahma D.2010."Faktor-faktor yang mempengaruhi profitabilitas Bank Syariah di Indonesia". Jurnal Bisnis dan Ekonomi, 9(2).pp.141-157.

Ghulam Ali Bhatti.2010."Evidence on Structure Conduct Performance Hypothesis in Pakistan Commercial Banks". International Journal of Business and Management. Vol.5,No.9 September 2010.

Imam Gozali.2007."Pengaruh CAR, FDR, BOPO, dan NPL terhadap Profitabilitas Bank Syariah Mandiri (Januari:2004-Oktober:2006)". http:www.kuliah.us.url. 
Lyla Rahma A. Dan Djoko Sampurno.2011."Analisis faktor-faktor yang mempengaruhi Profitabilitas (ROA)”. Jurnal Dinamika Ekonomi dan Bisnis,8 (1).pp.1-14.

Muh. Farhan Akhtar, Khizer Ali dan Shama Sadaqat.2011."Factors Influencing the Profitability of Islamic Banks of Pakistan". International Research Journal of Finance and Economics.issue 66,2011.

Osmad Muthaher.2012."Akuntansi Perbankan Syariah".Graha Ilmu: Jakarta.

Restiyana.2011."Analisis pengaruh CAR, NPL, BOPO, LDR, dan NIM terhadap Profitabilitas Perbankan (studi pada Bank Umum di Indonesia periode 2006-2010)".Skripsi, jurusan akuntansi Fakultas Ekonomi UNDIP Semarang.

Rida Rahim dan Yuma Irpa.2008."Analisa efisiensi operasional terhadap Profitabilitas pada Bank Umum Syariah dan Unit Syariah (studi kasus BSM dan BNI Syariah)".Jurnal Bisnis dan Manajemen.Vol.4,No.3,2008.

Sri Wahyuni ,K. 2012."Analisis Pengaruh CAR, NPL, LDR, NIM, dan BOPO terhadap Profitabilitas pada Perusahaan Perbankan di Indonesia (studi kasus Bank Devisa periode 2006-2010)".Skripsi, jurusan Manajemen Fakultas Ekonomi dan Bisnis Universitas Hasanudin Makasar.

Wibowo dan Syaichu.2013."Analisis pengaruh suku bunga, inflasi, CAR, BOPO, NPF terhadap Profitabilitas Bank Syariah".Jurnal Manajemen..Vol.2,No.2,2013.

Wihdan.2012.BI:Pertumbuhan Perbankan Syariah 2013 Positif.http://www.kompas.com

Yayu Anggraeni.2006."Analisis faktor-faktor yang mempengaruhi laba Bank Umum Syariah di Indonesia".Skripsi, jurusan Akuntansi Fakultas Ekonomi Institut Pertanian Bogor (tidak dipublikasikan).

Yuliani.2007."Hubungan Efisiensi Operasional dengan Kinerja Profitabilitas pada sektor perbankan yang go publik di Bursa Efek Jakarta".Jurnal Manajemen dan Bisnis Sriwijaya.Vol.5, No.10 Desember 2007.

Jurnal Akuntansi Indonesia 
LAMPIRAN

Tabel 1

\begin{tabular}{cccccc}
\hline \multicolumn{7}{c}{ Hasil Analisis Deskriptif Data } \\
\hline CAR & 48 & 3.83 & 20.23 & 12.6177 & 4.90006 \\
\hline FDR & 48 & 47.74 & 103.33 & 95.2442 & 8.13033 \\
\hline NPF & 48 & 2.42 & 5.90 & 3.8590 & .97428 \\
\hline REO & 48 & .59 & .91 & .7435 & .10977 \\
\hline BOPO & 48 & 67.61 & 98.39 & 81.3713 & 8.02912 \\
\hline ROA & 48 & 1.25 & 2.44 & 1.8550 & .28907 \\
\hline
\end{tabular}

Valid N (listwise)

48

Sumber: Data sekunder diolah, 2014

Tabel 2

Hasil Perhitungan Regresi Linier Berganda

\begin{tabular}{|c|c|c|c|c|c|c|}
\hline & \multirow[t]{2}{*}{ Model } & \multicolumn{2}{|c|}{ Unstandardized Coefficients } & \multirow{2}{*}{$\begin{array}{c}\begin{array}{c}\text { Standardized } \\
\text { Coefficients }\end{array} \\
\text { Beta }\end{array}$} & \multirow[t]{2}{*}{$\mathrm{t}$} & \multirow[t]{2}{*}{ Sig. } \\
\hline & & $\mathrm{B}$ & Std. Error & & & \\
\hline \multirow[t]{6}{*}{1} & (Constant) & 4.323 & .596 & & 7.254 & .000 \\
\hline & CAR & .026 & .011 & .433 & 2.338 & .024 \\
\hline & FDR & .009 & .003 & .260 & 2.817 & .007 \\
\hline & NPF & -.042 & .046 & -.142 & -.909 & .368 \\
\hline & REO & -1.530 & .282 & -.581 & -5.419 & .000 \\
\hline & BOPO & -.029 & .004 & -.810 & -6.619 & .000 \\
\hline
\end{tabular}

a. Dependent Variable: ROA

Sumber: Data sekunder diolah, 2014 
Tabel 5

Uji Multikolinearitas \& Nilai Tolerance dan VIF

Coefficients $^{\mathrm{a}}$

\begin{tabular}{cccc}
\hline \multirow{2}{*}{ Model } & \multicolumn{2}{c}{ Collinearity Statistics } \\
\cline { 2 - 4 } & \multicolumn{2}{c}{ Tolerance } & \multicolumn{1}{c}{ VIF } \\
\hline \multirow{3}{*}{1} & (Constant) & & \\
\cline { 2 - 4 } & CAR & .222 & 4.511 \\
\cline { 2 - 4 } & FDR & .891 & 1.122 \\
\cline { 2 - 4 } & BOPO & .508 & 1.967 \\
\hline & NPF & .311 & 3.211 \\
\hline
\end{tabular}

a. Dependent Variable: ROA

Tabel 6

Hasil Uji Durbin Watson

\begin{tabular}{ccccc}
\hline$d$ & $d l$ & Du & $4-d l$ & $4-d u$ \\
\hline 1,227 & 1,164 & 1,587 & 2,836 & 2,413 \\
\hline
\end{tabular}

Tabel 7

Hasil Uji Durbin Watson dengan Penambahan 1 Variabel Lag

Model Summary ${ }^{b}$

\begin{tabular}{lrrrrr}
\hline Model & $\mathrm{R}$ & R Square & $\begin{array}{c}\text { Adjusted } \mathrm{R} \\
\text { Square }\end{array}$ & $\begin{array}{c}\text { Std. Error of the } \\
\text { Estimate }\end{array}$ & Durbin-Watson \\
\hline 1 & $.838^{\mathrm{a}}$ & .702 & .657 & .16334 & 1.752 \\
\hline
\end{tabular}

a. Predictors: (Constant), lag_ROA, CAR, REO, FDR, BOPO, NPF

b. Dependent Variable: ROA 
Tabel 8

\begin{tabular}{|c|c|c|c|c|c|c|}
\hline \multicolumn{7}{|c|}{ Coefficients $^{a}$} \\
\hline & \multirow{2}{*}{ Model } & \multicolumn{2}{|c|}{ Unstandardized Coefficients } & \multirow{2}{*}{$\begin{array}{c}\begin{array}{c}\text { Standardized } \\
\text { Coefficients }\end{array} \\
\text { Beta }\end{array}$} & \multirow{2}{*}{$\mathrm{t}$} & \multirow{2}{*}{ Sig. } \\
\hline & & B & Std. Error & & & \\
\hline \multirow[t]{6}{*}{1} & (Constant) & 4.323 & .596 & & 7.254 & .000 \\
\hline & CAR & .026 & .011 & .433 & 2.338 & .024 \\
\hline & FDR & .009 & .003 & .260 & 2.817 & .007 \\
\hline & NPF & -.042 & .046 & -.142 & -.909 & .368 \\
\hline & REO & -1.530 & .282 & -.581 & -5.419 & .000 \\
\hline & BOPO & -.029 & .004 & -.810 & -6.619 & .000 \\
\hline
\end{tabular}

a. Dependent Variable: ROA

Tabel 9

\begin{tabular}{cccccccc}
\hline \multicolumn{8}{c}{ Hasil Uji F } \\
\hline \multirow{3}{*}{1} & Model & Sum of Squares & Df & Mean Square & $\mathrm{F}$ & Sig. \\
\cline { 2 - 7 } & Regression & 2.673 & 5 & .535 & 17.893 & $.000^{\mathrm{a}}$ \\
\cline { 2 - 7 } & Residual & 1.255 & 42 & .030 & & \\
\cline { 2 - 7 } & Total & 3.927 & 47 & & & \\
\hline
\end{tabular}

a. Predictors: (Constant), REO, FDR, NPF, BOPO, CAR

b. Dependent Variable: ROA

Tabel 10

Hasil Uji Koefisien Determinasi

\begin{tabular}{ccccc}
\hline Model & $\mathrm{R}$ & $\mathrm{R}$ Square & $\begin{array}{c}\text { Adjusted } \mathrm{R} \\
\text { Square }\end{array}$ & $\begin{array}{c}\text { Std. Error of the } \\
\text { Estimate }\end{array}$ \\
\hline 1 & $.825^{\mathrm{a}}$ & .681 & .642 & .17284 \\
\hline
\end{tabular}




\section{Gambar 1}

Uji Normalitas
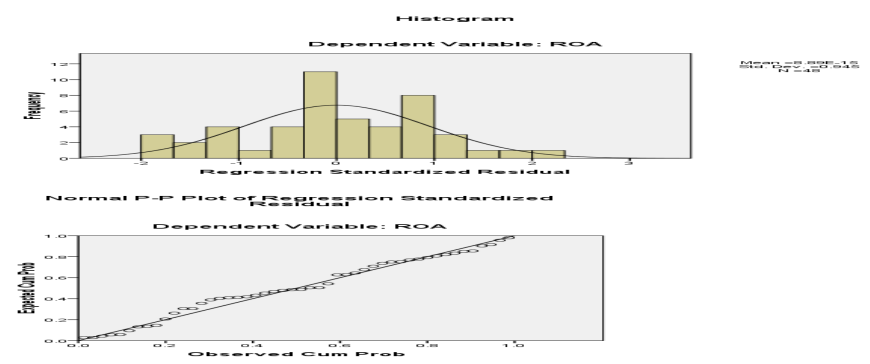

soateonio

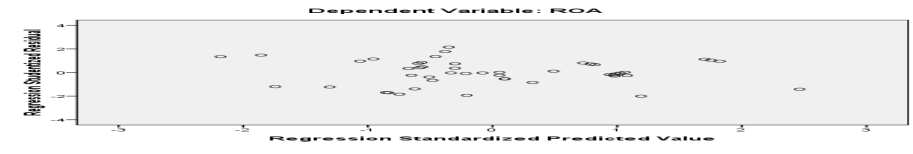

\section{Gambar 2}

Uji Heteroskedastisitas
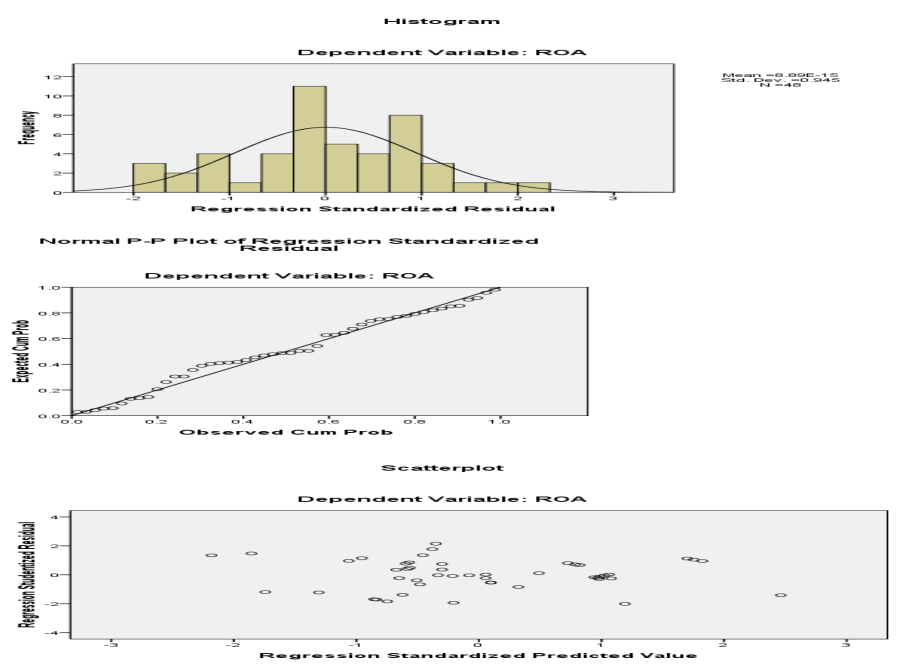

Gambar 3

Daerah Uji Autokorelasi

\begin{tabular}{cccccc}
\hline $\begin{array}{c}\text { Autokorelasi } \\
\text { positif }\end{array}$ & Daerah ragu-ragu & $\begin{array}{c}\text { Tidak ada } \\
\text { autokorelasi }\end{array}$ & Daerah ragu-ragu & Autokorelasi negatif \\
\hline 0 & 1,164 & $\mathbf{1 , 2 2 7}$ & 1,587 & 2,413 & 2,836 \\
\hline
\end{tabular}

